\title{
THE STUDY OF INSTILLING PLURALITY VALUES TO THE STUDENTS OF ISLAMIC SCHOOLS IN MAKASSAR
}

\author{
Hamdan Juhannis \\ UIN Alauddin, Makassar - Indonesia
}

\begin{abstract}
This study tries to discuss the central issue of the instilling plural values to learners of each level of Islamic schools in Makassar. This study focuses on Islamic schools, since the teaching of religious subjects were also offered at public schools. In order to limiting the scope of the research, this study highlights on the extent of religious teaching and how the teaching are synchronized with of the plurality values in schools that consists of diverse ethnicity and culture in one hand, and diverse religious beliefs outside the schools, in another hand. The main problem statement is how the plurality values are instilled at Islamic schools in Makassar. The instilling process of plural values is tilled at Islamic schools in Makassar. The instilling process of plural values and culture is qualitative with socio-cultural pedagogical approach. The finding is that the instilling of the plurality values had been implemented but is not yet an adequate process, because it is still sporadic. Also, it is not yet concretely reflected in the curriculum.
\end{abstract}

Keywords: Instilling of plurality values, Islamic school.

\section{Introduction}

By the looks of Indonesian geography, natural resources, and demographic circumstances, there are a lot of privileges given by God to this country. They are not only the country's fertile soil, water flowing swiftly, oil, minerals, precious natural resources, and thousand types of plants and animals species, but also its amazing population diversity. Personal identity backgrounds of Indonesians are also highly different. Traditions and customary are so varied from one community to others and each with their peculiarities. 
These facts have never ever been deliberately created and formatted. This condition is naturally created by the development of thought and condition of Indonesian society. Unfortunately, this potential is only administered for seasonal purposes, tourism, and cultural needs which are managed for economy and globalization purposes. This fact might only owned by nations such as Indonesia. When at a specific time, these resources could become a hot ball if they are not managed properly.

The globalization era confronts religious communities to a series of new challenges that are not too different to what has been experienced before. Plurality of religions, inter or inter-religious conflict is a real phenomenon. In the past, religious life were relatively more peaceful. It was because religious people were as if living in isolated camps away from outside world's challenges. In contrast to the present days, there are a lot of ambiguous and worrying statements must be carefully addressed by religious people.

In this context, religion was referred to a cultural symptom. As a cultural system, religion became a force mobilization and establishment that triggering problems or conflicts. This condition occurred when the religion was functioned as a culture in a real community. As a result, the religion would create a very paradoxical reality. On one hand, it can be used as an instrument of integration but on the other hand, the religion turned out to be a disintegration factor. ${ }^{1}$

Along with an increasing trend of loosening integrative nationstate-community bonds due to political fragmentation and an ongoing economic crisis, open conflicts and violence also increased among various groups of people. The conflicts and violence were originally rooted in political issues or political rivalries, struggling for economic resources due to the worsening economic crisis, in turn, also involves the use of religion or at least the use of religious symbolism. Although it is clear that such conflicts could not be reduced to a mere conflict between religions. The conflicts and violence, in the end, turned into

\footnotetext{
${ }^{1}$ Further explanation about religion as conflicts political tools in a context of modern society see Brenda Watson, "Democracy, Religion and Secularism: Reflections on the Public Role of Religion in a Modern Society," in Journal of Beliefs and Values, Vol. 32, No.2 (2011), pp. 173-183.
} 
large scale of conflicts and higher level of violence among religious communities that never happened in the history of Indonesia. ${ }^{2}$

The development above shows a tendency of religious radicalization at religious groups in Indonesia. Or at least, searching efforts for authentic and actualization of religion with political ties is arisen. Thus, it encourages and strengthens potential disintegrative conflict in this country.

Therefore, replacement of religion on its proportion as the sublime divine teachings should be one of the nation's main agendas. However, should be noted that religion is not an independent variable in the community, nation and state life. In other words, empirical actualization and expression of religion associated with other aspects of life such as economic, political, legal, social, cultural, education and so forth. As a result, the arrangement of religious and morality in the nation and state buildings, it is a necessity to have an inclusive understanding of religion. ${ }^{3}$

In a social context, functional relationship between religion and society as long as emphasizing on rational and humanistic aspects could be classified as a historical force that determining the changes and the development of the society. ${ }^{4}$

Harmonious constructions built proudly were just like a fragile and easily destroyed spider's web. Theological harmony established during the new order regime was passive and static. Therefore, it failed to capture symptoms of impending and collapsed harmony of nation and state. Besides that, education in Indonesia touched only little aspects of how to respect the religious beliefs and rich cultural diversities.

Pluralism in nature is a characteristic that had been embedded in the nation of Indonesia since long time ago even before the existence of Islam. This characteristic had grown and emerged as religions and local beliefs such as Buddhism and Hinduism. Both religions have portrayed the history of Indonesia up to now. Although the plurality cannot be separated from Indonesia, efforts to instilling plurality values

\footnotetext{
2 Azyumardi Azra, Visi Indonesia Masa Depan di Bidang Agama (Jakarta: Badan Litbang Agama dan Diklat Keagamaan, 26 September, 2002), p. 4.

${ }^{3}$ Models of inclusive teaching of religion see in Michael J. Cuyjet et al., Multiculturalism on Campus: Theories, Models, and Practices for Understanding Diversity and Creating Inclusion (Chicago: Stylus Publishing, 2001).

${ }^{4}$ Alex R. Rodger, Education and Faith in an Open Society (Britain: The Handel Press, 1982).
} 
always face many challenges. Pluralism is not only about a language of differences but also interests, involvements and participations. The plurality language is also the language to support exchanges, dialogues and debates. Some thoughts when defined pluralism as the ability to do anything were just unprincipled relativism.

Pluralism in subsequent studies should be actually classified into social science. It is because the pluralism deals with diversities and differences and cannot be separated from life. Therefore, it deserves people's comprehensive examinations and studies. Formally, learners are the most appropriate example of a comprehensive understanding of this diversity conditions. ${ }^{5}$

This understanding needs to be instilled earlier to students, formally and informally. Actually, the learners, so far, have experienced the pluralities. Each learner has more than one identity, or has several components of identity. A woman could be a child, a mother or a wife to a husband. Public schools or Islamic schools/madrasah are the most strategic and appropriate way to instill a unity in differences. The students will leads to an increasing heterogeneous situation and condition of the community, the nation and the states, sooner or later. The learners will definitely be in the middle of various environment background.

Early instilling process of the pluralism concept to the learners is expected to have a positive impact on their futures at least, during their periods as students or when they grow older. In the process of their education, a variety of religious thoughts can be studied in a systematic, conceptual, and rational way from different point of view. Trying to develop a dialogue, learning, understanding and sharing a religion's good teachings and faiths with other religions, as well as developing a mission would create real peace and fraternity among religion followers. Therefore, the students will eventually understand diversities as a blessing.

The instilling process of an understanding is certainly not out of teacher's role. The teacher is a pioneer in the instilling process of plural values as a a blessing in the community. Thus, all schools elements, principals, teachers, school committees/community will be involved in

\footnotetext{
${ }^{5}$ Explanation about efforts to include pluralism in social science in M. R. Olneck, "The recurring dream: Symbolism and ideology in intercultural and multicultural education," American Journal of Education, No. 98 (1990), pp. 147-174.
} 
the instilling plurality values, at least this effort is encapsulated in the lesson plan.

Based on this reason, this study tried to discuss the central issue of the instilling plural values to learners in Makassar. This study focused on learners at Islamic schools because of the teaching of religious subjects at Islamic schools is more than at public schools. In a specific way, it deals with three issues as follows: (1) To what extent Islamic schools' efforts in instilling the plurality values to the students?; (2) What plurality values offers to students by teachers at various levels of Islamic schools?; (3) How is the learners respond to plural values they learnt at Islamic schools?

In order to limiting scope of the research, this study highlights the extent to which religious teaching at Islamic schools has taught religious meaning to students. Moreover, to what extent the associated elements at the Islamic schools provided guidance to the students in instilling the plurality values. Islamic schools in Makassar since would certainly be interesting to be discussed. It is because at the Islamic schools in Makassar we would see a synchronization of the plurality values learning and teaching that had diverse aspects of ethnicity, religion, and culture.

\section{Perspectives on Plurality and Plural Education}

The relationship of education with the plurality values as part of efforts to reduce conflicts caused by misunderstandings about diversity or pluralism is an intriguing issue. Zuhairi Misrawi's book Al-Qur'an Kitab Toleransi, Inklusivisme, Pluralisme, dan Multikulturalisme (the Koran the Book of Tolerance, Inclusivism, Pluralism, and Multiculturalism). ${ }^{6}$ According to Misrawi, the Qur'an as an open book full of inclusiveness and tolerance. To Misrawi, Prophet Muhammad reaffirmed that Islam comes to earth to improve and beautify previous religions, especially Judaism and Christianity. The prophet brought a message the oneness of God and Humanity. The Misrawi's book described the verses of tolerance: the Qur'an as a book of tolerance.

Jalaluddin Rahmat in his book Islam dan Pluralisme, Akblak Qur'an Menyikapi perbedaan (Islam and Pluralism, the Qur'an's Morality Dealing

\footnotetext{
${ }^{6}$ Zuhairi Mizrawi, al-Qu'rān Kitab Toleransi, Inklusivisme, Pluralisme dan Multikuluturalisme (Jakarta: P3M-Fitrah, 2007).
} 
with Differences) ${ }^{7}$ reviewes Islam as a flexible, moderate, and full of religious tolerance as its graces. Rahmat revealed a number of verses which have lost their meanings and put Islam as a simply polite and loving religion to its followers only, not to other religions' followers. Islam is not just limited to the Islam as an ideology but more than that. Islam is a positive inspiration to the community's association. At the beginning chapter of this book, Rahmat described the essence of faith in the middle of plural truths that explain how is our attitudes to this religion. Further explanations in this book described verses related to pluralism.

Abdurrahman Wahid's Islamku-Islam Anda-Islam Kita (My Islam Your Islam- Our Islam), ${ }^{8}$ a collection of Wahid's thoughts describes and translates a quite straightforward ideas of Islam in the context of Indonesia, nationalism, pluralism, democratization and indigenization as well as the relationship between Islam and the state. Mohammad Fathi Osman's book, The Children of Adam: an Islamic Perspective on Pluralism 9 presents historical data about harmonius relationship between Islam and other religions that have a long history of practicing pluralism. Although this book is not the the only reference, it could gave great contributions in building up a global pluralism. Pluralism has always been a problem when it comes to the economic system, political ideology and social structure let alone to the issue of religions. The rising of truth claims and salvation claims in the name of faith are widespread phenomena found in the community.

When Religion Becomes Evillo by Charles Kimball vividly explored why the religion followers stuck on the concept of religious truth claims which is absolute and sole. It reviews religion as a matter of problem, absolute truth, and blind obedience. Said Aqil Siradj's book Islam Kebangsaan, Fiqib Demokratik Kaum Santri, (Islam Nationality, The

\footnotetext{
${ }^{7}$ Jalaluddin Rahmat, Islam dan Pluralisme, Akblak Qur'an Menyikapi Perbedaan (Jakarta: Serambi Ilmu Semesta, 2006).

8 Abdurrahman Wahid, Islamku, Islam Anda, dan Islam Kita (Jakarta: The Wahid Institute, 2006).

9 Mohammad Fathi Osman, The Children of Adam: an Islamic Perspective on Pluralism (Washington DC: Center for Muslim-Christian Understanding, George University, 1996).

${ }^{10}$ Charles Kimball, When Religion Becomes Evil (Bandung: Mizan, 2005).
} 
Democratic Fiqh to Santri ${ }^{11}$ discusses how Islam still referres to the nationality aspect. Islam never opposed to nationalism. Precisely, on the foundations of nationalism Islam could grow flourishly in Indonesia. By keeping the five principles of Pancasila as the state ideology, Islam still played its role to drive people to take part in achieving welfare goals. A merger between nationalism and Islam in terms of Indonesian state is another form of political system in Islam. In other words, in a person's religious bigotry, nationalism still plays an important role.

Plural education is understood as a process of education following the principles of democracy, equality, and justice. Plural education oriented to humanity, unity, togetherness and peace. By this form of education, it is expected to develop attitudes such as acknowledgement of plurality, accepting and appreciating diversities in life.

To implement the essence of plural education above, the writer's study based on the development of multicultural education theory from Donna M. Gollink, James A. Banks, and James A. Lynck. From this theory, the writer gaines an important point that multicultural education can be characterized from the components aspects in it. Multicultural education curriculum must have educational programs that pay attention to the learners' ethnic background, language and culture. Multicultural education should include concepts such as the concept of multicultural diversity, respect, fairness, tolerance, racism, prejudice, discrimination, and stereotypes. ${ }^{12}$

The concept of democratic education offered by Michael Glassman is also interesting to be a cornerstone concept in this study. According to Glassman, educators need to master models of democracy applied by other nations when teaching the plurality values in the classroom. By this understanding, the learners can reflect on how the models of democracy work and in what situation these models appropriate in social practices. ${ }^{13}$

\footnotetext{
11 Said Aqil Sirad, Islam Kebangsaan Fiqh Demokratik Kaum Santri (Jakarta: Fatma Press, 1999).

${ }^{12}$ Donna M. Gollinck, "Strategies for Multicultural Education," in Donna M. Gollinck and Philip C. Chinn, Multicultural Education in a Pluralistic Society (London: The CV Mosby Company, 1983), p. 305.

13 Michael Glassman, "Five Classroom: Different Forms of Democracies and their Relationship to Cultural Pluralism," Journal of Educational Philosophy and Theory, Vol. 43, No. 4 (June 2011): pp. 365-386.
} 
From Islamic Perspectives circles, review about the concepts of the instilling plural values done by some scholars such as 'Abd Allah bin Ibrähim al-Lațif in his book Tasämuh al-Gharb ma'a al-Muslimin. Latif discusses tasämub (tolerance), al-'adl (fairness), al-rahmah (merciful), and al-ihsān (the doing of good) concepts as prerequisites for realizing peaceful pluralistic society. ${ }^{14}$ Other multicultural concept is Muhammad Imärah's concept of al-ta'addudiyab (pluralism) and altanawnu' (diversity) in Islam. This concept could be a reference when discussing plural education in Islam. According to Imarah, it is because the plural values rooted in the history of Moslems' social behaviours, including in their educational system. However, the challenge of plurality in the Islamic world including in the educational system was due to decline of Islamic civilization, especially when dealing with Western hegemonies.The effect of the decline of civilization, the Moslems sometimes seek compensations by covering themselves from other developed and advanced nations or countries. ${ }^{15}$

Other theoretical basis as the basis of this study is from James A. Banks who developed a model of multicultural education curriculum. According to Banks, the multicultural education curriculum could be developed by integrating multicultural teaching materials into the multicultural curriculum. For this purpose, Banks offered two stages: an additive level and a transformative level. According to him, the additive level is carried out by introducing the concepts and new themes associated with the plurality into the existing curriculum. This method is very easy to be applied. Because of its implementation is without changing the existing curriculum structure. Meanwhile, the transformative level is made by instilling the concepts and themes related to pluralism and incorporate religious views and perspectives into the curriculum. This second method is more difficult than the first method. It is because this method applied by changing the structure of the existing curriculum, but it appeared to be more comprehensive. ${ }^{16}$

\footnotetext{
14 'Abd Allāh bin b. Ibrāhim al-Lațif, Tasāmuḥ al-Gharb ma'a al-Muslimin fī al-'Asr alHāạir (Riyāạ: Dār Ibn al-Jawzìi, 1999), pp. 23, 43, 55, and p. 57.

15 Muhammad Imārah, al-Islam wa al-Ta'addudìyah: Al-Ikbtilä wa al-Tanawnu' fर̀ Itar alWị̣dat, translated into Indonesian by Abdul Hayyie al-Katanie (Jakarta: Gema Insani Press, 1997), p. 31.

${ }^{16}$ James A. Banks, "Integrating the Curiculum with Ethnic content," in James A. Banks and Cherry A. McGee Banks, Multicultural Education: Issues and Perspectives (Boston: Allyn and Bacon, 1989), p. 92.
} 
Based views above, it can be stated that the foundation theories of plural education that could be instilled by educators are full of creative learning developments including connections with relevant subjects to the plurality. The theories above also clearly offered important curriculum in favor of the plural values to be applied in the classroom. But some of the theories suggested that education is not simply related to the plurality learning in the classroom referring to the curriculum and syllabus but also what is no less important is the application of those values in a real life of individuals and groups, either in an educational environment or in the community.

\section{Efforts of Islamic Schools in Makassar in Instilling Plurality Values}

Based on the research done, it is found that there are significant efforts done by the educations in instilling plural values to the students in Islamic educational institutions in Makassar. It can be stated that their efforts are varied. The majority of educations instill the plural by integrating the plurality messages with the religious lessons they teach. In general they argue that the religious teachings are very relevant with the teachings of plurality. Ramli Rasyid, for example, argued that the teaching akidah akhlak is very relevant, because when teaching akidah, it is related to the theological perspectives. He stated that to create students with plural perspectives, it is important to fix their theological understanding. Furthermore, he stated that akhlak is related to the ethics of students in facing plural cases. According Ramli Rasyid, ${ }^{17}$ a teacher of Akidah Akblak (Theology and Ethic) of MAN 1 makassar, when a teacher of akidah akblak is successful in integrating plural values in his or her subject, the teaching plurality and pluralism will be successful in Islamic schools. On the contrary, Ramly added, that when the teacher of akidah akhlak fail to deliver plurality messages in the subject, it will also ruin the plurality values in schools. Therefore, he suggests that there should be efforts by the government, that is, the Islamic educational sections of the religious ministry to do refreshement training of plurality among educators of this subject.

What Ramli pointed out is very relevant with the statement of Muliyati, ${ }^{18}$ another teacher of MAN 1 Makassar, who pointed her concern to improve the teaching of plurality in Islamic schools in

\footnotetext{
${ }^{17}$ Interview with Ramli Rasyid, Makassar 5 March 2012.

${ }^{18}$ Interview with Mulyati, Makassar 5 March 2012.
} 
Makassar. She stated that the success of the plural teaching depend on the quality of teachers and their attitude of plurality itself, especially the religious subjects teachers. She pointed the facts in his schools, teachers are in the same concern of the importance of teaching plurality. She said that some teachers think this issue is important but they did not make significant efforts to integrate the teaching in their subject. They keep teaching textually based on syllabi and curriculum offered. They relate the issue when it is really related without doing any modification. Even, what mostly happened, teachers are well trained enough to instill plurality values in teaching the subjects.

What Muhammad Saleh, ${ }^{19}$ Vice Headmaster of MTsN Biringkanaya pointed in his schools was even more critical. He stated that the efforts of instilling plurality in the Islamic schools are not only the job of religious subject teachers but all teachers, included general subject teachers. If it is only expected from teachers of religious subjects, the teaching of the plurality will be not intensive. Futhermore, he stated that there should not be dyhotomic system of teaching plurality, because the messages of plurality values are not only for those aspects of lives which are related to religious affairs, but also for many public affairs. However, Saleh pointed out the problems in his schools, that faced by teachers in terms of instilling plurality. First, teachers are still not in the same concept of the essence of plurality. They are not in the same understanding how plurality and pluralism should be understood. He himself described his understanding that plurality values covering aspects of lives included cultural and religious diversities. But may be for other teachers, plurality is only related to cultural aspects. The second problem by the teachers, as Saleh pointed, is that teachers of non-religious subjects have methodological and substantial problems in campaining the plurality values. For examples, teachers of mathematics did not know well how in each or in some subtopics of his lessons plural values can be integrated.

Saleh's point is in accordance with one of the non religious teachers interviewed, Sitti Ramlah, ${ }^{20}$ the teacher of Mathematics. She is basically aware of the importance of plural values to insert to students to teach them to live together peacefully, but the problem is the difficulty to relate the values with the subjects taught to the students.

${ }^{19}$ Interview with Muhammad Saleh, 19 March 2012.

${ }^{20}$ Interview with Sitti Ramlah, 19 April 2012. 
She admits that the teachers should be creative to use sometimes to convey the plural values but because the demands of curriculum that may the efforts difficult to be done in the classroom.

Efforts of inserting plural values in the Islamic schools are also seen quite interesting in MAN 1 Makassar. According to Amiruddin, ${ }^{21}$ the Principle of school, there have been efforts to improve the capacity of educators of schools through teachers gathering program. Basically, the speechers invited is not only related to plurality issues, but the school think it is important to deal with this issues, due to the great number of ethnic and religious clashes happening in the media. By improving the capacity of the teachers, they are hoped to transfer their plurality knowledge to their students. Even, in certain time, for example, in Ramadhan month, the Pesantren Kilat for all students, are also program to do issues related to plurality values.

The Principle, however, pointed out that this efforts still strongly depended on the good will of the school heads, included headmaster and vice headmasters. It is still not part of the school system. He worried that the leadership changes the concerns of the plurality insertion will also decrease. Related to this concern, he also pointed that plurality values instilment is also related to the concern of school educators. It can happen that if one school have teachers with the background of exclusive Islam, it is very possible that the teaching of plurality will not be found there. What Amiruddin pointed out seems true because as the researcher found in certain Islamic schools in Makassar, male students are separated from female, and male students did not shake hands with female students and female teachers. ${ }^{22}$

Based on the above discussions, it can be stated that there is an efforts of instilling plural values in Islamic schools in Makassar. However, the efforts are varied and tend to be sporadic. There still not be same concepts in particular schools. The efforts still done by many religius subjects teachers but non religious subject teachers still lack of efforts. Even, plural values still strongly depend on the policy of the internal schools and still much in informal way of instilling. Curriculum seems not help significantly to the instilling process.

\footnotetext{
${ }^{21}$ Interview with Amiruddin, 21 April 2012.

22 This situation was observed in one of Private Islamic Schools in Makassar, Al Fityan School
} 


\section{Aspects of Plurality Values Instilled to the Students of Islamic Schools in Makassar}

In general, aspects of plural teachings implemented by the educators that pluralilty teachings are based on perspectives of many people from different background. Futhermore, they agree that the teaching plurality should also be based on the understanding that there is no single right interpretation of historical facts. The principle of implementing plurality teachings should eradicate stretyped view on race, culture and religion.

Among the teachers of Islamic schools interviewed, it is found that they started to instill the importance of plurality values by looking at the policy of the schools. Wahyuddin ${ }^{23}$ the Principle of MTsN Model Makassar, stated that they started to implement plurality values by making sure that there is no single policy that block the plurality teaching in the school. He continued that when policy give open spaces of plurality teaching, it is already an indication of the beginning of the success in the plurality teachings, because when the policy is not supportive, efforts of the teachers will not be maximum. He gave an example, that in his schools gender issues in terms of the structure of school is no longer an important issue. He stated that whoever has a comptetent to sit in as the leader of program held in the school, he or she will given more room to actualize his or her competence. In terms of the details aspect plurality values taught, many teachers are more interested in anti-radicalist perspectives, democratic and just principles, brotherhood, sameness, tolerance, solidarity, equality, equity, and diversity.

As found in MAN Model Makassar, the implementation of the above aspect is through the teaching in the classroom and the practice among students. Jamaluddin, ${ }^{24}$ a teacher of MAN Model Makassar, stated that even though there is only a single religious followers among the students in the Islamic schools, but the classroom consist of students with different ethnic background. The way the school practiced the understanding diversity is by preventing the students to stereotype other students from different ethnic groups. Any students found to insult other students will be punished by the school. He stated that this important because understanding the diversity is not

${ }^{23}$ Interview with Wahyuddin, 25 March 2012.

${ }^{24}$ Interview with Jamaluddin, 26 March 2012. 
only in the classroom but become values adopted by the students when meeting the same situation in the community. He stated that classroom should reflect the society in general and classroom is basically a miniature of society, especially in terms of diversity.

When the researcher asked other teacher in different schools, whether they practice the plural teaching of understanding diversity in the real life of school as found in MA madani Makassar, Andi Ahru, ${ }^{25}$ the Principle of this school, said that his school still do not far reach the situation. However, as found in his schools, equality is important in the school. There is always a balance of the number of male and female students in the classroom. In sending the students to join some competition, gender issues is always a priority. This does not mean that female students should be more supported but simply is equality. In the schools he taught, he said that it was found that more female students have good grades compared to male students. He stated for this case, male students should be pushed more than female. He stated that is the essence of gender issues, which is not only related to female but also to male ones.

The other aspect of plural teaching that become major concern of the teachers is preventing the students to be cautious with what is called by religious exclucivism. Teachers stated that religious exlusivism are the perception on the excellence of certain religion and ignoring other religious good messages. According to teachers this kind of spirit was basically possessed by any religious followers. According to them, it is important to be careful with this kind of religiosity because many students still consider the verse, 'the only accepted religion in the hands of Allah is Islam'. This is basically the same as the doctrine in Catholic in which in many of its followers adopt extra ecclessim, which is devided into extra ecclessiam nulla salus (there is no safety outside church), extra ecclessiam nullus prophet (there is no prophet outside church), and extra ecclessiam nulla gratia (there is no grace outside church).Afifuddin, ${ }^{26}$ a teacher of MA Pesantren An Nahḍah who was interviewed, said that exclusivity spirit among people, included the students can result in the exclusivity spirit as subject and object of violence. It usually started with theological conflict, but later on escalating with open conflict with accompanied with violent actions.

\footnotetext{
${ }^{25}$ Interviw with Andi Ahru, 28 March 2012.

${ }^{26}$ Interview with Afifuddin, 3 April 2012.
} 
Besides inclusive, equality, and diversity nature of plural teachings, the researcher also found from some schools in Makassar use the curriculum contents to teach brotherhood in Ethics subject (akidah akblak). In the curriculum of Islamic senior high schools brotherhood which is called in Islamic terms as ukhuwah is emphasized. However, according to Hj. Maryam, ${ }^{27}$ teacher of MA Ulul Albab, the teaching of ukhuwah is only more emphasized in ukhuwah Islamiyah. In his opinion, if a school will really want to teach the nature of pluralism, it should also equally emphasize with other kinds of ukhuwah. As noted in the concepts of ukhuwah, besided ukhuwah Islamiyah (Islamic brotherhood), it is also recognized ukhuwah insaniyah (mankind brotherhood), ukhuwah wațaniyah (same country brotherhood), ukhuwah imaniyah (believers brotherhood). She stated that if we want to give more effects to the students of the understanding of brotherhood, they should not only be introduced to Islamic brotherhood, should also learn how to build brotherhood among people, no matter name of religions they follow. According to Abdul Salam, ${ }^{28}$ teacher of Mts Pondok Pesantren Madinah, this understanding needs a commitment, because it may be that some teachers only accept that brotherhood can only with same religious followers. When the researcher ask this issue in other school Salam's worry above seems to be true, because as Nurul Fajriah, ${ }^{29}$ teacher of MAN Biringkanaya admits that since students of Islamic high schools only from one religious followers, that is Islam, the educators of akhlak only emphasize more on Islamic brotherhood. The reason of doing this is that the teacher did not want to take the risk to lead the students misinterpret the meaning of brotherhood itself. As she noted that she did not want her students to be liberal in understanding the nature of brotherhood in Islam.

Based on the above findings and discussions, it can be inferred that there are some issues that become priority by Islamic schools in Makassar in teaching plurality values. Important issues found are anti radicalism, religious tolerance, gender equality, and understanding diversity. However, it can be concluded that aspects of plurality values instilled are still not based on the consensus of many schools in

\footnotetext{
${ }^{27}$ Interview with Hj. Maryam, 3 April 2012.

28 Interview with Abdul Salam, 4 April 2012.

${ }^{29}$ Interview with Nurul Fajriah, 5 April 2012.
} 
Makassar. Some see the subject put in the curriculum to teach brotherhood as parts of plurality values, some thought the important of instilling inclusive nature of Islam. The advance of plurality values can even be seen in the way some Islamic schools in Makassar to introduce gender equality. However, they did not yet try to differentiate between the nature of equality and equity, in which equality is much more oriented to fairness in quantity, while equity is also related to fairness in quality. It is also found that in Elementary schools, the plurality is much more concrete teaching, that is, the diversity nature of humans' life. In secondary schools it started to touch issues related to reason why people from different culture and religion should be treated equally

\section{Students' Responses to the Teaching of Plurality Values in Islamic Schools in Makassar}

What is meant here by responses is the attitude of students after they got the teaching of plurality values in the schools they studied. Of course, it is hard to measure the attitude as a result of a learning of certain values. But what is measured in this research is the acknowledgement of the school elements, especially the educators, students acknowledgment of the values which is supported by the observation of the students' attitude relating to the plurality issues.

When the researher interviewed Hasbullah, teacher of MAN Model Makassar, he acknowledged that responses of the students seemed to be productive. He stated that almost there is no fighting among the students caused by the tribal clashes. He stated that even though the school tightly regulated and punished students who was found to insult other students based on gender, tribes, and cultures, it seems that peaceful condition of the students is not only caused by the regulation, but also by the growth of awareness to live together.

When tried to confront this information to Ahmad Ridha, ${ }^{30}$ a the third year student of MAN Model, he agreed that it is right the school made the tight regulation and the students followed it well. But he himself as a person originated outside Makassar already learnt a lot of diversity from his environment outside the school. He stated the job of his father, as a staff in certain private company made him move from one city to another in Indonesia, and directly this mobility made him learn about understanding tribal and religious diversity. When the

\footnotetext{
${ }^{30}$ Interview with Ahmad Ridha, 12 April 2012.
} 
researcher asked Muhamamd Fatih ${ }^{31}$ who was originally from Makassar, he agreed that all students are treated equally without looking at their tribes of origin. However, when he was asked about understanding and appreciating other religious followers, he stated that the only true religion is Islam and other religion should not be appreciated because they are wrong. When he was asked whether he had neighbors from different religion, he answered that in the housing complex he lived there was a Christian family but he never talked to them. When asked again whether his teacher told him to appreciate other religious followers, he answered that the teacher once told the students to do so, but it is from the teaching of his parents that he adopted that those are from religious followers should not be made friends because they will influence him to enter to his religion

It is interesting to probe the attitude of the students dealing with other religious followers in their neighborhood. The researcher asked Putri, ${ }^{32}$ a student of Islamic elementary school, she said that in front of his house there was Christian family. Like other friends in her community, she also made friend with her. She came to the house of her Christian friends too. But she never it something there because here parents asked her not to eat there because her Christian neighbor has dogs and her parents worried if the food was also touched by the dogs before. When asked to her whether the Christian family was not offended if she reject the food offered by them, she answered that since she rejected once of the offer, the family never offer foods anymore.

When tried to conform this situation to the teacher of the school, Andi Rasyidah, ${ }^{33}$ she admited that the school did not yet go so far to break the students understanding of the relation with other religious followers. She said first, some teachers in the school also held the same perception of the students. Furthermore, she herself would not do further interference because he was afraid to be misunderstood by the parents of the students that resulted the clashes between school and the students parents. She said that he should treat this issue very carefully, because it is very much connected with ideological issues.

\footnotetext{
${ }^{31}$ Interview with Muhammad Fatih, 12 April 2012.

32 Interview with Putri, 19 April 2012.

${ }^{33}$ Interview with Andi Rasyidah, 23 April 2012.
} 
Also, she added, the students of elementary school did not yet understand the essence of pluralism.

This is different from the case of the Islamic secondary school. Bunayya, ${ }^{34}$ when teaching about brotherhood, she asked the students who practiced about making friends even though from different religions. Many students raised their hands. Then she explained that that was great because Islamic teaching did not limit Muslims to meet and make relations with other people from different religions. One students even asked the possibility to go to the church with his friends, but the teacher stated that the students can go to church like nonMuslim friends can go to mosques. However, she emphasized that the visit to other religion's worship house is not for worship but social matters.

Based on the above findings, it can be concluded that the responses of the students in Islamic schools are varied based on the level of their schools that indicate their maturity, and based on the way they were taught in the schools, and the doctrines received from their parents. In general, the students started to understand the nature of plurality. Moreover, many students in Islamic schools in Makassar practiced plurality unconsciously, especially when going along with their neighbor friends in their community from different tribes and cultures. The only problem of plurality faced by the students when they deal with persons from different religious followers. They seemed to be reluctant to open themselves. Many of them were still limited by the doctrines of missionaries of religions, a suspicion that they want to be influence to convert to new religious belief.

\section{Conclusion}

The results of this study indicates that the activity of instilling the plurality values to students at Islamic schools in Makassar had been conducted. Based on the above findings and discussions, it can be inferred that there are some issues that become priority by Islamic schools in Makassar in teaching plurality values. Important issues found are anti radicalism, religious tolerance, gender equality, and understanding diversity. However, it can be concluded that aspects of plurality values instilled are still not based on the consensus of many schools in Makassar. Some saw the subject put in the curriculum to

\footnotetext{
${ }^{34}$ Interviw with Bunayya, 24 April 2012.
} 
teach brotherhood as parts of plurality values, some thought the important of instilling inclusive nature of Islam.

The advance of plurality values can even be seen in the way some Islamic schools in Makassar to introduce gender equality. However, they did not yet try to differentiate between the nature of equality and equity, in which equality is much more oriented to fairness in quantity, while equity is also related to fairness in quality. It is also found that in Elementary schools, the plurality is much more concrete teaching, that is, the diversity nature of humans' life. In secondary schools it started to touch issues related to reason why people from different culture and religion should be treated equally.

Teachers have made efforts to instill the plurality values by integrating these messages into teaching subjects, not only with religious subjects but also non-religious subjects. However, religious subjects teachers tended to do more plurality value teachings compared to non-religious teaching. The problems of non-religious subject teachers are their lack of competency in integrating the plurality values to their subjects they taught.

This research also concluded that instilling the plurality values is not yet adequate because it is sporadic and has not been concretely reflected in the curriculum. Highlighted issues in the instilling process is related to basic human rights that may not be violated, including freedom to express religious beliefs, cultural diversity and equality without discriminations. Plurality values are also presented with emphasis on the ukhuwwah insaniyah aspects (brotherhood among human beings). Students' responses to these plurality values, in terms of their understandings; the need for leaving together peacefully. However, in practice, especially from elementary school students still behave exclusively. They limit themselves to make friends with friends in their community who were from other religious followers. This situation was much excerbated by the doctrines from their parents and the reluctance of ther teachers to openly teach the essence of pluralism.]

\section{Bibliography}

\section{Books and Articles}

Al-Attas, al Sayyed Muhammad an Naquib. Aims and Objectives of Islamic Education. Jedah: King Abdul Aziz University, 1979. 
al-Lațî̄i, 'Abd Allāh bin Ibrāhìm. Tasamuḥ al-Gharb ma'a al-Muslimin fī al-'Așr al-Häàir. Riyāẹ: Dār Ibn al-Jawzì, 1999.

Azra, Azyumardi. Visi Indonesia Masa Depan di Bidang Agama. Jakarta: Badan Litbang Agama dan Diklat Keagamaan, 2002.

Banks, James A. "Integrating the Curriculum with Etnic content," in James A. Banks dan Cherry A. McGee Banks, Multicultural Education: Issues and Perspectives. Boston: Allyn and Bacon, 1989.

Burneett, Gary. Varieties of Multicultural Education: An Introduction. New York: Eric Publication, 2001.

Cassanova, Jose. Public Religions in the Modern World. Chicago and London: The University of Chicago Press, 1994.

Charles R. Kniker. You and Values Education. Colombus, Ohio: A Bell and Howell Company, 1997.

Cuyjet, Michael J. et al. Multiculturalism on Campus: Theories, Models, and Practices for Understanding Diversity and Creating Inclusion. Chicago: Stylus Publishing, 2001.

Ecick, Diana L. A New Religious America: How a Christian Country has Become the World's Most Religiously Diverse Nation. New York: Harper Sam Francisco, 2001.

al-Fadl, Khalid Abu. The Place of Tolerance in Islam. Bandung: Arasy, 2002.

Finch, Curtis R. and John R. Cruncilton. Curriculum Development in Vocational and Technical Education. Boston and London: Allyn and Bacon, 1993.

Glassman, Michael Glassman. "Five Classroom: Different Forms of Democracies and their Relationship to Cultural Pluralism." Journal of Educational Philosophy and Theory, Vol. 43, No. 4., June 2011.

Gollinck, Donna M. "Strategies for Multicultural Education." in Donna M. Gollinck and Philip C. Chinn. Multicultural Education in a Pluralistic Society. London: The CV Mosby Company, 1983.

Gollinck, Donna M and Philip C. Chinn. Multicultural Education in a Pluralistic Society. London: The CV Mosby Company, 1983.

Haberman, M. "The nature of Multicultural Teaching and Learning in American Society." Journal of Education, Vol. 65, 1999. 
al-Lațīīi, 'Abd Allāh bin Ibrāhìm. Tasāmuḥ al-Gharb ma'a al-Muslimīn fí al-'Ass al-Hädir. Riyāẹ: Dār Ibn al-Jawzì, 1999.

Imārah, Muḥammad. Al-Islām wa al-Ta'addudìyah: al-Iktilāf wa alTanawnu' fì Itar al-Wihddat. Jakarta: Gema Insani Press, 1997.

Lynch, James. Multicultural Education: Principles and Practices. London: Rutledge and Kegan Paul: 1986.

Kertinger, Fred N. Foundation of Behavior Research. New York: Holt and Winston Inc., 1973.

Kimball, Charles. When Religion Becomes Evil. Mizan: Bandung, 2005.

Mizrawi, Zuhairi. Al-Qur'an Kitab Toleansi, Inklusivisme, Pluralisme, dan Multikulturalisme. Jakarta : P3M-Fitrah, 2007.

Mouw, Richard J. and Sander Griffon. Pluralism and Horizon. New York: William B. Erdmann Publishing Company, 1993.

Olivia, Peter F. Developing the Curriculum. New York: Harper and Collins Publisher Inc., 1992.

Olneck, M. R. "The Recurring Dream: Symbolism and Ideology in Intercultural and Multicultural Education." American Journal of Education, Vol. 98, 1990.

Osman, Muhammad Fathi. The Children of Adam: an Islamic Perspective on Pluralism. Washington DC: Center for Muslim-Christian Understanding, George University, 1996.

Rahmat, Jalaluddin. Islam dan Pluralisme, Akblak Qur'an Menyikapi Perbedaan. Jakarta: Serambi Ilmu Semesta, 2006.

Ramayulius. Metodologi Pengajaran Agama Islam. Padang: Kalam Mulia, 1994.

Rodger, Alex R. Education and Faith in an Open Society. Britain: The Handel Press, 1982.

Sachedina, Abdul Aziz. The Islamic Roots of Democratic Pluralism. New York: Oxford University Press, 2001.

Schwarz, Adam. A Nation in Waiting. New South Wales: Allen and Unwin, 1999.

Seligman, A. The Idea of Civil Society. New York: The Free Press, 1992.

Siradj, Said Aqil. Islam Kebangsaan Fiqib Demokratik Kaum Santri. Jakarta: Fatma Press, 1999. 
Smith, Mark K. Curriculum Theory and Practice. London: Rutledge, 2002.

Stewart, J. In E. H. Cheatham \& Associates (eds.). Cultural Pluralism on Campus. Alexandria VA: American Association for Counseling and Development, 1991.

Wahid, Abdurrahman. Islamku, Islam Anda, dan Islam Kita. Jakarta: The Wahid Institute, 2006. 